\title{
Problems of primary T-cell lymphoma of the thyroid gland -A case report
}

\author{
Junkichi Yokoyama ${ }^{1 *}$, Shin Ito ${ }^{1}$, Shinichi Ohba ${ }^{1}$, Mitsuhisa Fujimaki ${ }^{1}$, Eriko Sato ${ }^{2}$, Norio Komatsu², \\ Katsuhisa Ikeda ${ }^{1}$ and Makoto Hanaguri ${ }^{3}$
}

\begin{abstract}
In the following report we discuss a very rare case of malignant T-cell lymphoma of the thyroid gland that developed in a 70-year-old woman with a past history of hypothyroidism due to chronic thyroiditis. The chief complaint was a rapidly growing neck mass. CT and ultrasonographic examination revealed a diffuse large thyroid gland without a nodule extending up to $13 \mathrm{~cm}$. Although presence of abnormal lymphoid cells in the peripheral blood was not found, the sIL-2 Receptor antibody and thyroglobulin measured as high as $970 \mathrm{U} / \mathrm{ml}$ and $600 \mathrm{ng} / \mathrm{mL}$ respectively. Fine needle aspiration cytology diagnosed chronic thyroiditis. A preoperative diagnosis of suspicious malignant lymphoma of the thyroid gland accompanied by Hashimoto's thyroiditis was made, and a right hemithyroidectomy was performed to definite diagnosis. Histological examination revealed diffuse small lymphocytic infiltration in the thyroid gland associated with Hashimoto's thyroiditis. Immunohistochemical examination showed that the small lymphocytes were positive for T-cell markers with CD3 and CD45RO. The pathological diagnosis was chronic thyroiditis with atypical lymphocytes infiltration. However, Southern blot analysis of tumor specimens revealed only a monoclonal T-cell receptor gene rearrangement. Finally, peripheral T cell lymphoma was diagnosed. Therefore, the left hemithyroidectomy was also performed one month later. No adjuvant therapy was performed due to the tumor stage and its subtype. The patient is well with no recurrence or metastasis 22 months after the surgical removal of the thyroid. As malignant T-cell lymphoma of the thyroid gland with Hashimoto's thyroiditis was difficult to diagnose, gene rearrangement examination needed to be performed concurrently.
\end{abstract}

Keywords: Peripheral T-cell lymphoma, Thyroid, Hashimoto's thyroiditis, Molecular diagnosis, Gene rearrangement

\section{Background}

Malignant lymphoma of the thyroid gland is uncommon, representing only 2 to $5 \%$ of all thyroid malignancies, and is often associated with autoimmune disorders, such as Hashimoto's thyroiditis [1]. Many reported cases are B-cell lymphomas of the thyroid, which include marginal zone B cell lymphoma of the mucosa-associated lymphoid tissue (MALT) type (maltoma) and diffuse large Bcell lymphoma. Primary T-cell lymphomas are extremely rare at less than $2 \%$ of all primary lymphomas of the thyroid gland. The present case report describes a rare case of primary T-cell lymphoma associated with Hashimoto's thyroiditis that was difficult to diagnose pathologically. It

\footnotetext{
* Correspondence: jyokoya@juntendo.ac.jp

'Department of Otolaryngology, Head and Neck Surgery, Juntendo University School of Medicine, Tokyo, Japan

Full list of author information is available at the end of the article
}

was, therefore, useful to diagnose through means of genetic study.

\section{Case report}

A 70-year-old woman was referred to our clinic, complaining of rapid anterior swelling at the neck. A diffuse firm goiter was observed and the patient indicated feeling oppression of the neck. No lymph node swelling was observed. The patient has a past history of hypothyroidism and enlargement 10 years earlier and takes $50 \mu \mathrm{g}$ levothyroxinesodiumdaily. Laboratory examination indicated almost normal thyroid function (free T4 $1.3 \mathrm{ng} / \mathrm{dL}$, free T3 $3.6 \mathrm{ng} / \mathrm{dL}$, thyroid-stimulating hormone (TSH) $0.04 \mathrm{~m}$ unit $/ \mathrm{mL}$, thyroglobulin $600 \mathrm{ng} /$ $\mathrm{mL}$ ) with anti-microsome antibodies and anti-thyroglobulin antibodies. The s-IL-2 Receptor antibody measured as high as $970 \mathrm{U} / \mathrm{ml}$.

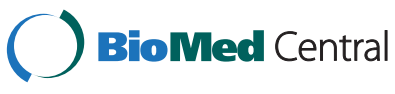


However, thyroxine-supplementation could not decrease the size of the thyroid. The thyroid gland continued to enlarge and diffuse, and was approximately $5 \mathrm{~cm}$ thick at the isthmus portion on the ultrasonographic examination. A computed tomography (CT) scan showed a huge thyroid enlargement with decreased internal density (Figure 1). There was no obvious mass lesion in the thyroid. The enlarged thyroid gland was well demarcated.

On FDG-PET ( ${ }^{18}$ F-fluorodeoxy glucose-Positron Emission Tomography) examination, the FDG accumulation was detected in the enlarged thyroid region, suggestive of Hashimoto's thyroiditis and/or lymphoma. Serological examinations were negative for human T-cell lymphoma virus type 1 (HTLV-1). Fine needle aspiration cytology suggested the case was consistent with Hashimoto's thyroiditis. Although we suspected possible malignant lymphoma associated with Hashimoto's thyroiditis from the large thyroid size and a rapid growth rate, the diagnosis was not confirmed. Therefore, the right hemithyroidectomy was performed to obtain a definite diagnosis and relief of the local symptoms caused by an enlarged goiter (Figure 2). Histological examination revealed diffuse small lymphocytic infiltration in the thyroid gland associated with Hashimoto's thyroiditis. However, Southern blot analysis of tumor specimens revealed only a monoclonal $\mathrm{T}$-cell receptor gene rearrangement. The final diagnosis was peripheral $\mathrm{T}$ cell lymphoma. Therefore, a left hemithyroidectomy was also performed one month later. No adjuvant therapy was performed because of the tumor stage and its subtype. The patient has been well with no recurrence or no metastasis. Furthermore, no additional medication has been required for 22 months since the surgery.

\section{Pathological findings}

Macroscopically, the resected thyroid gland was diffusely enlarged, but the thyroid tumor was firmly encapsulated without extracapsular spread. The cut surface of the thyroid had pale white medullary components.
Histologically, severe and diffuse infiltration of the lymphoid cells was found in the medullary region. Lymph follicle formation with germinal centers was noted in the periphery of the medullary region. Atypical lymphoid infiltrations were also located among the atrophic thyroid follicles.

In the medullary area, infiltrated lymphoid cells were relatively uniform, small-to-medium sized, round cells with a high nuclear to cytoplasmic $(\mathrm{N} / \mathrm{C})$ ratio. These cells had round nuclei with increased coarse chromatin and small nucleoli. Mitotic figures were often seen as high as $60 \%$ in high-power fields (Figure 3). These findings suggested small lymphocytic lymphoma. The atrophic thyroid epithelia showed enlarged and eosinophilic granular cytoplasm with large nuclei, so-called Hürthle cell metaplasia. Around these Hürthle cells there were many plasma cells, lymph follicles with germinal centers and a few eosinophils (Figure 3). These findings suggested complication of Hashimoto's thyroiditis.

Immunohistochemical examinations were performed on formalin-fixed, paraffin-embedded specimens, using an autostaining system according to the manufacturer's protocol. From these results, diffusely infiltrated lymphocytes were positive for T-cell markers (CD3 and CD45RO) and positive for B-cell markers (CD20). However, infiltrated atypical T cells showed CD3 dominancy (Figures 3 and 4). In contrast, lymphoid cells of the peripheral area with lymph follicles showed an admixture of T and B cells, mimicking lymph follicles.

\section{Flow cytometry}

Surface marker analysis of the freshly resected tumor showed T-cell dominancy (CD2+, CD3+, CD4+, CD5+, CD45+). There was also a small population of B-cell lineage, with no dissociation of surface membranous immunoglobulin light chain kappa or lambda. These data suggest the polyclonal nature of infiltrated B lymphocytes associated with Hashimoto's thyroiditis.
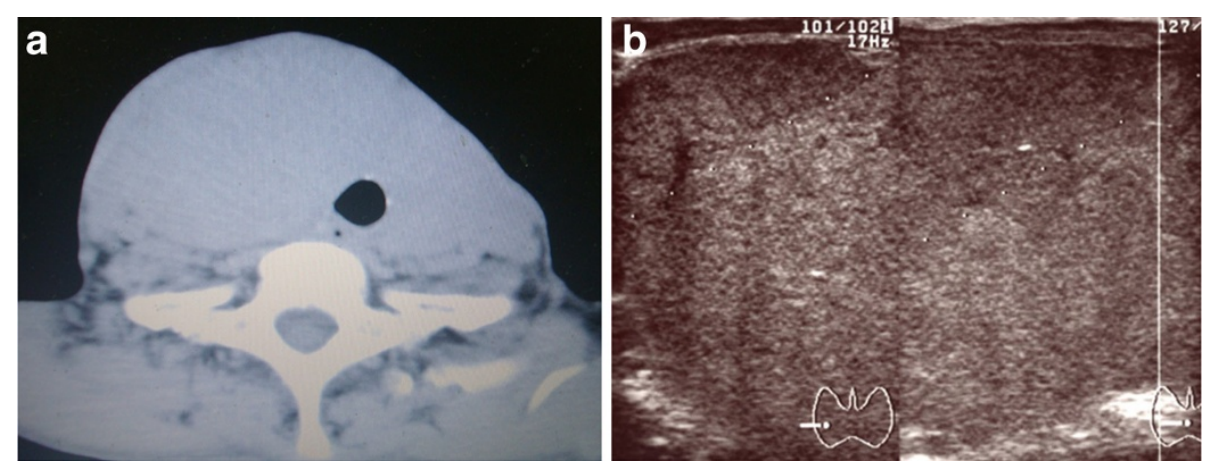

Figure 1 CT and ultrasonographic examination. (a) CT shows the diffuse enlarged thyroid gland without nodule. (b) Ultrasonographic examination demonstrates a homogenous enlargement of the thyroid gland not so low echogenecity as typical malignant lymphoma. 


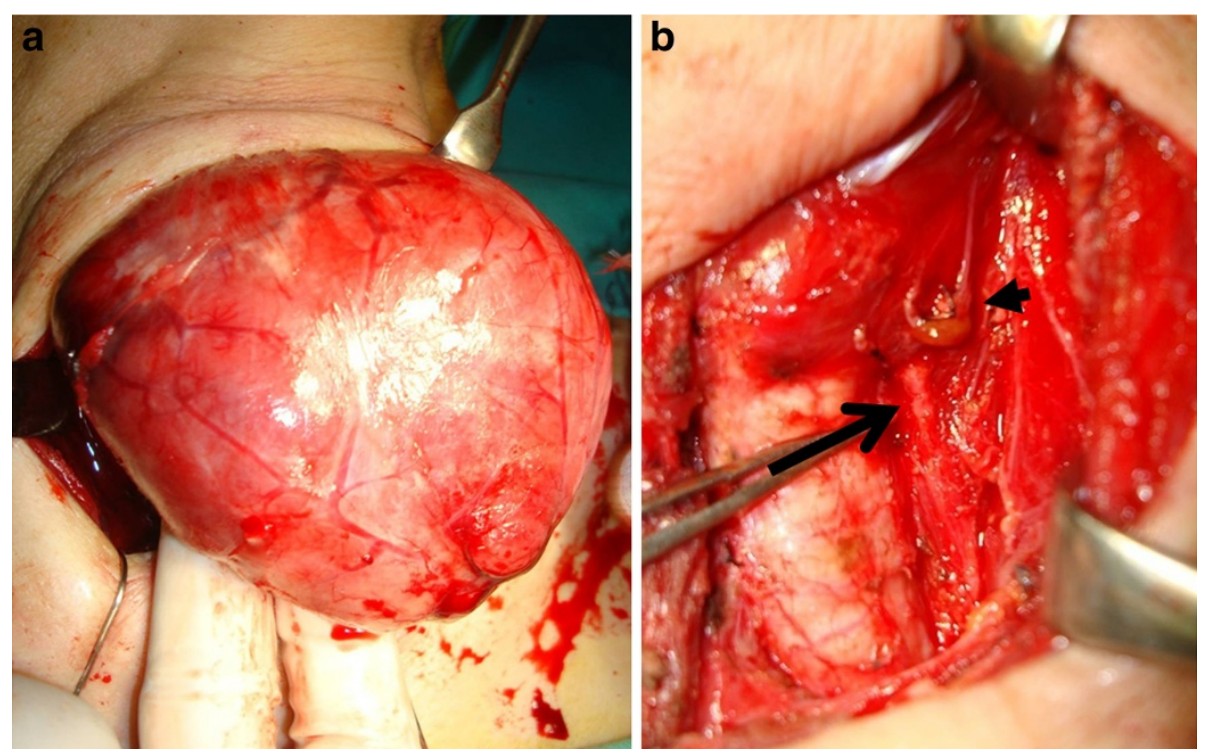

Figure 2 Operative findings. a) First operative finding: the right hemithyroidectomy was performed without any complication. b) Second operative finding: the arrow indicates a left recurrent laryngeal nerve. The arrow head indicates a parathyroid gland with supplying artery.
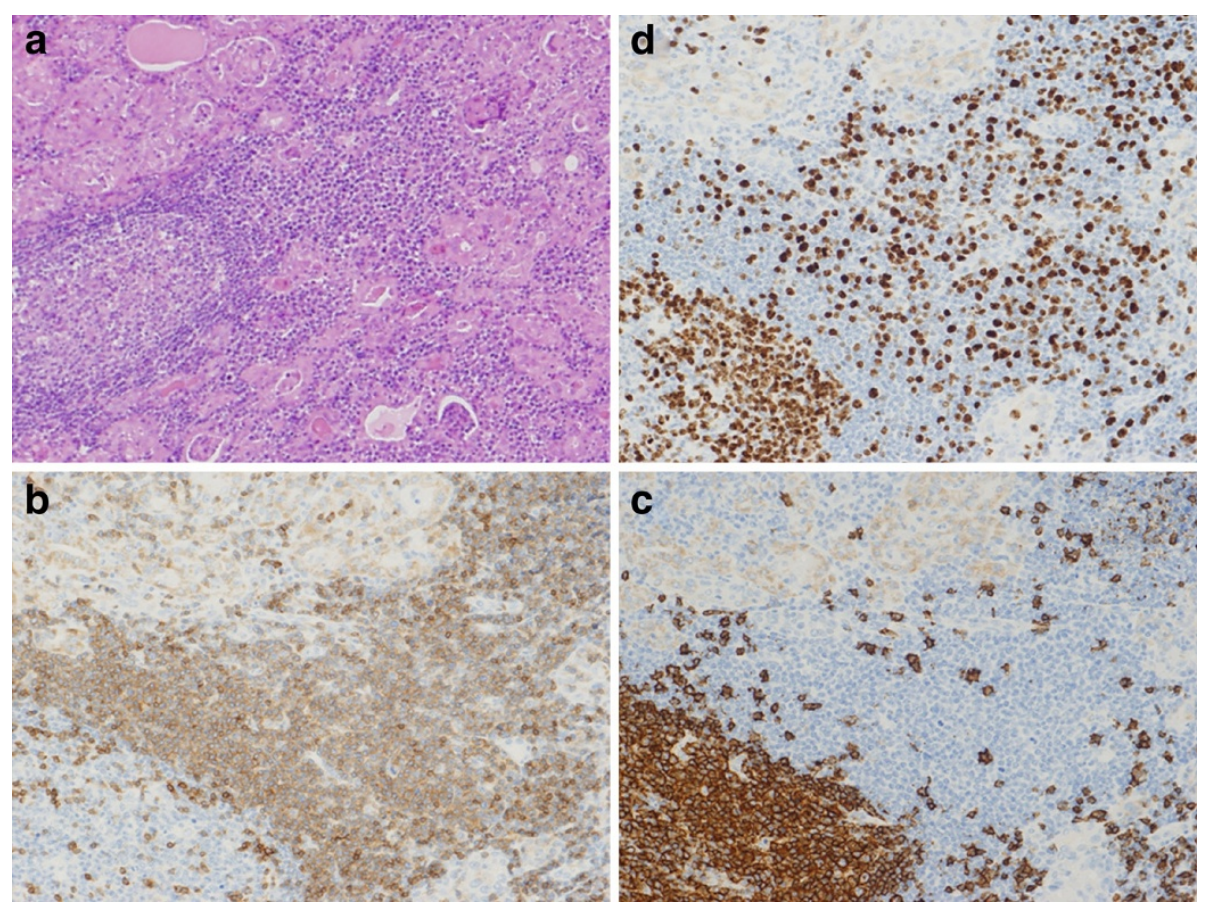

Figure 3 Microscopic findings and immunohistochemical staining. (a) Low-power view of histological examinations revealed massive infiltration of small monotonous lymphocytes, which were difficult to distinguish tumor cells from reactive lymphocytes in Hashimoto's thyroiditis. (Hematoxylin and eosin staining, X100). (b) Immunohistochemical staining showed that tumor cells had T-cell markers for CD3, (X400). (c) Immunohistochemical staining by CD20 showed infiltrated lymphoid cells had B-cell markers, (X400). (d) MIB staining. MIB 1 index was as high as $60 \%$ in high-power fields, (X400). 


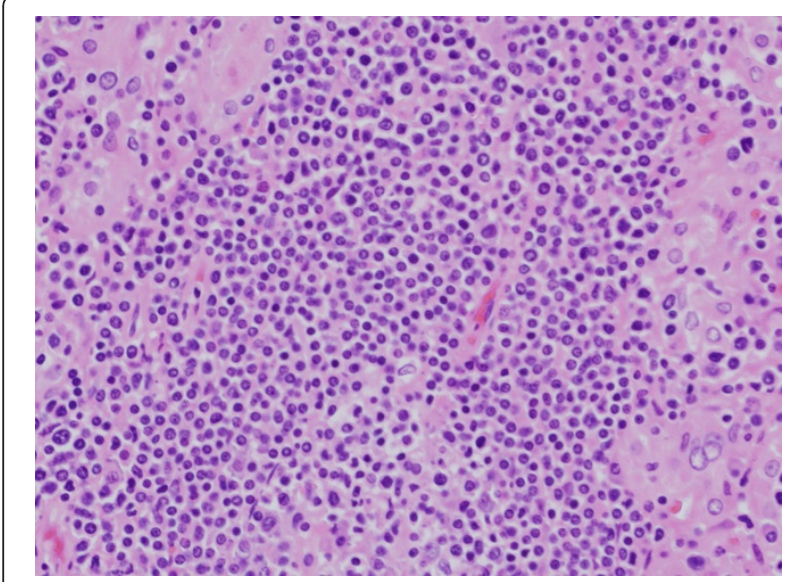

Figure 4 High power magnification. (Hematoxylin and eosin staining, X400). With the high-power view, tumor cells had a high nuclear to cytoplasmic (N/C) ratio, coarse nuclear chromatin with prominent nucleoli.

\section{Molecular analysis}

Polymerase chain reactions (PCR) for detection of rearrangement of immunoglobulin heavy chain (IgH) hypervariable region and T-cell receptor (TCR) were performed using fresh specimens as described previously [2]. PCR showed a polyclonal pattern for both $\operatorname{IgH}$ and TCR. Southern blot analysis produced a rearrangement band of TCR- $\gamma$ by Hind III digestion and TCR- $\beta$ by BamH I digestion (Figure 5). There was no rearrangement of the $T C R-\delta$ chain or $\operatorname{IgH}$.

\section{Discussion}

We diagnosed peripheral T-cell lymphoma of the thyroid gland associated with Hashimoto's thyroiditis using molecular analysis. No other organ involvement of lymphoma was demonstrated, including the lymph nodes, the mediastinum and the bone marrow. Therefore, we considered this case to be a rare primary T-cell lymphoma of the thyroid gland, clinical stage I E-A with bulky mass.

However, malignant lymphoma is a minor component of thyroid tumors, accounting for only 2 to $5 \%$ of all thyroid malignancies. Malignant lymphoma of the thyroid gland is often associated with Hashimoto's thyroiditis [1]. Most thyroid lymphomas are of the B-cell type, including maltoma and diffuse large B-cell lymphoma. T-cell lymphoma of the thyroid gland is extremely rare with only 15 cases reported in literature (Table 1) [3-15]. Most patients had a past history of Hashimoto's thyroiditis, which affected female subjects more than male subjects. Most patients also had a history of rapid thyroid enlargement, sometimes accompanied with hoarseness or dysphasia. Open biopsy was the most common method of diagnosis; however, it is difficult to make a reliable diagnosis of thyroid malignant lymphoma. In the present case, a hemithyroidectomy was performed without a biopsy. Progression of malignant lymphoma in the thyroid was suspected from the clinical course, such as rapid growth and an enlarged thyroid tumor associated with Hashimoto's thyroiditis.

Histological examinations revealed massive infiltration of small monotonous lymphocytes, which were difficult to distinguish from reactive lymphocytes in Hashimoto's thyroiditis.
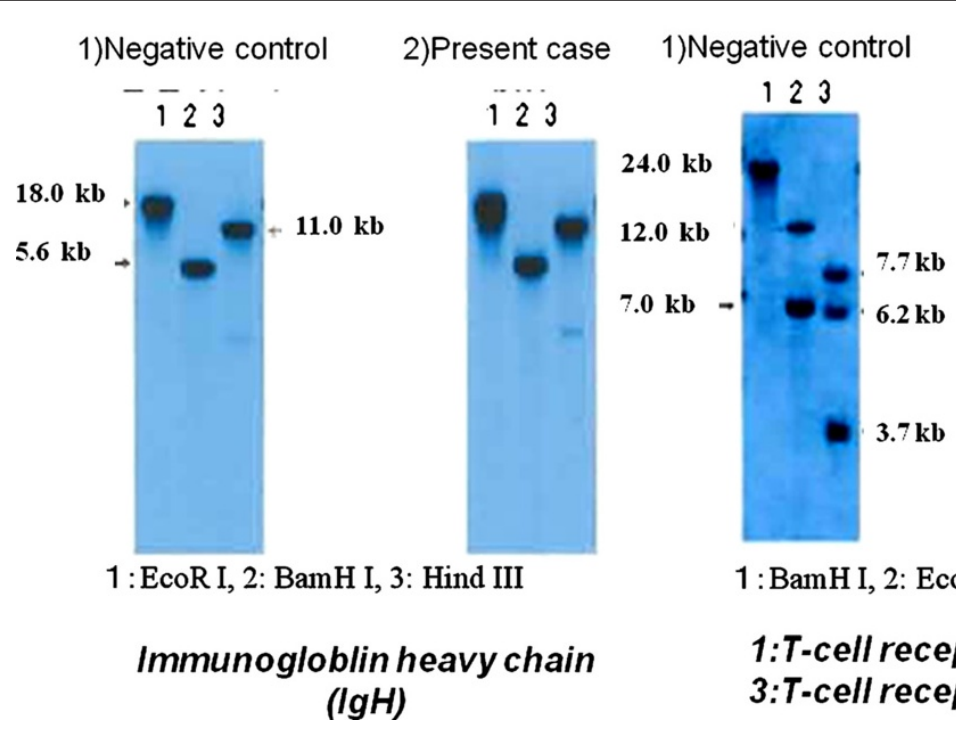

2)Present case

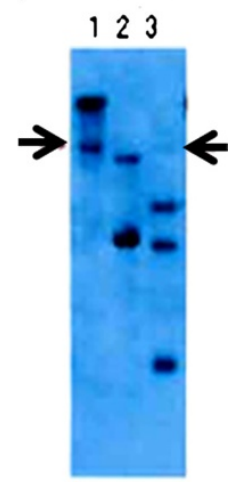

1 : BamH I, 2: EcoR V, 3: Hind III

\section{1:T-cell receptor(TCR)- $\beta 1$ 3:T-cell receptor(TCR)-V}

Figure 5 Southern blot analysis (rearrangement). (a) Rearrangement of the immunogloblin heavy chain (lgH) were negative, and (b) rearrangements of T-cell receptor (TCR)- $\beta 1$ (lane 1) and TCR- $\gamma$ (lane 2) were found in the present case. Rearrangement of TCR- $\delta$ was negative in the present case. M, molecular weight marker; 1, normal control (human placental DNA); 2, present case. 1, BamH I; 2, EcoR V; 3, Hind III. 
Table 1 Lists of previously reported thyroid T-cell lymphoma

\begin{tabular}{|c|c|c|c|c|c|c|c|c|c|}
\hline References* & Age/gender & Presentation & Chronic thyroiditis & HTLV-1 & Histology & Molecular Diagnosis & Diagnostic intervention & Therapy & prognosis \\
\hline [3] 1977 & $73 / F$ & & N/A & N/A & & & & $S+R$ & $\begin{array}{l}\text { alive at } \\
24 \text { months }\end{array}$ \\
\hline [4] 1990 & 79/M & Goiter & N/A & N/A & Diffuse small cleaved & & open biopsy & $C+R$ & alive at 4 years \\
\hline [4] 1990 & $80 / F$ & Goiter & $(+)$ & N/A & Diffuse small cleaved & & Hemithyroidectomy & S & DUC \\
\hline [5] 1996 & $64 / F$ & $\begin{array}{l}\text { Thyroid mass, } \\
\text { Hypothyroidism }\end{array}$ & $(+)$ & $(-)$ & $\begin{array}{l}\mathrm{CD} 2+, \mathrm{CD} 3+, \mathrm{CD} 5+ \\
\text { CD45RO+ }\end{array}$ & $\begin{array}{l}\text { TCR- } \beta, \text { TCR- } \gamma \\
\text { rearrangement }\end{array}$ & Total thyroidectomy & $S+C+R$ & $\begin{array}{l}\text { alive at } \\
9 \text { months }\end{array}$ \\
\hline [6] 1997 & $59 / F$ & Goiter & $(+)$ & $(-)$ & $\begin{array}{l}\text { CD3+, CD4-, CD8-, } \\
\text { CD19- }\end{array}$ & TCR- $\delta$ rearrangement & Open biopsy & $C+R$ & $\begin{array}{l}\text { alive at } \\
22 \text { months }\end{array}$ \\
\hline [7] 1999 & $65 / M$ & $\begin{array}{l}\text { Thyroid mass, } \\
\text { Horseness, } \\
\text { dyspasia, }\end{array}$ & $(-)$ & N/A & $\begin{array}{l}\text { CD45RO+, CD45-, } \\
\text { vimentin+ }\end{array}$ & & Open biopsy & $C+R$ & $\begin{array}{l}\text { died at } \\
11 \text { months }\end{array}$ \\
\hline [8] 1999 & $39 / F$ & $\begin{array}{l}\text { Goiter, fever, } \\
\text { dysphonia }\end{array}$ & $(+)$ & N/A & $\begin{array}{l}\text { CD30+, CD45RO+, } \\
\text { CD3-, CD20-, } \\
\text { CD79a-, CD21- }\end{array}$ & & Open biopsy & $C+R$ & alive at 1 year \\
\hline [9] 2000 & $63 / F$ & $\begin{array}{l}\text { Thyroid mass, } \\
\text { Hoarseness, } \\
\text { dyspnea }\end{array}$ & $(+)$ & N/A & CD45RO+, CD43+ & & Total thyroidectomy & $S+C+R$ & alive at 3 years \\
\hline [10] 2001 & $72 / \mathrm{M}$ & $\begin{array}{l}\text { Thyroid mass, pressure, } \\
\text { difficulty swallowing }\end{array}$ & $(+)$ & N/A & CD4+ & & Right hemithyroidectomy & $C+R$ & $\begin{array}{l}\text { alive at } \\
12 \text { months }\end{array}$ \\
\hline [11] 2005 & $71 / \mathrm{F}$ & $\begin{array}{l}\text { Thyroid swelling, } \\
\text { horseness, goiter }\end{array}$ & $(+)$ & $(-)$ & $\mathrm{CD} 3+, \mathrm{CD} 45 \mathrm{RO}+, \mathrm{CD} 4+$ & $\begin{array}{l}\text { TCR- } \beta, \text { TCR- }- \\
\text { rearrangement }\end{array}$ & Total thyroidectomy & S & alive at 25 months \\
\hline [12] 2005 & $86 / F$ & Swelling of neck & $(-)$ & $(-)$ & $\begin{array}{l}\mathrm{CD} 3 \mathrm{e}+, \mathrm{CD} 5+, \mathrm{TIA}-1+ \\
\text { (T-cell restricted antigen) }\end{array}$ & $\begin{array}{l}\text { TCR-C } \beta \\
\text { rearrangement }\end{array}$ & Left hemithyroidectomy & s & alive at 2 years \\
\hline [13] 2007 & $34 / M$ & N/A & $(-)$ & $(-)$ & $\begin{array}{l}\text { CD3+, CD5+, CD7-, } \\
\text { CD43+, CD45RO+, } \\
\text { CD20- }\end{array}$ & & N/A & $S+C+R$ & $\begin{array}{l}\text { died at } \\
13 \text { months }\end{array}$ \\
\hline [14] 2007 & $61 / M$ & Thyroid mass & $(+)$ & $(-)$ & $\mathrm{CD} 3+, \mathrm{CD} 4+$ & TCR- $\beta$ rearrangement & Open biopsy & C & alive at 4 years \\
\hline [14] 2007 & $68 / M$ & $\begin{array}{l}\text { Thyroid mass, } \\
\text { dyspnea }\end{array}$ & $(+)$ & $(-)$ & CD3+, CD4+, TCR-ab+ & & Open biopsy & C & $\begin{array}{l}\text { died at } \\
5 \text { months }\end{array}$ \\
\hline [15] 2008 & $32 / \mathrm{M}$ & $\begin{array}{l}\text { Swelling of neck, } \\
\text { fatigue, shortness of } \\
\text { breath }\end{array}$ & $(-)$ & N/A & $\mathrm{CD} 3+$ & $\begin{array}{l}\text { TCR- } y \\
\text { rearrangement(PCR) }\end{array}$ & Open biopsy & C & alive at 1 year \\
\hline present & $70 / F$ & Neck swelling & $(+)$ & $(-)$ & CD3+, CD45RO+, & $\begin{array}{l}\text { TCR- } \beta, \text { TCR- } \gamma \\
\text { rearrangement }\end{array}$ & Total thyroidectomy & s & $\begin{array}{l}\text { alive at } \\
20 \text { months }\end{array}$ \\
\hline
\end{tabular}

References*, Number in brackets indicate reference numbers and other numbers indicate published year; N/A, not available; C, chemotherapy; DFS, disease-free survival; DUC, died of unrelated cause; IgH, immunoglobulin heavy chain; PCR, polymerase chain reaction; $R$, radiation therapy; $S$, surgery; TCR, T-cell receptor. 
Immunohistochemical examination showed that these lymphocytes had T-cell markers (CD3 and CD45RO). However, the first pathological diagnosis could not accurately diagnose $\mathrm{T}$-cell lymphomas. There are some reasons for the misdiagnosis in the current case. First, Hashimoto's thyroiditis induced complicated massive infiltration of small lymphocytes, which were stained with B cell markers and $\mathrm{T}$ cell markers. It was difficult to distinguish tumor cells from reactive lymphocytes in Hashimoto's thyroiditis. Second, T-cell lymphomas of the thyroid gland are very rare and cannot be easily referred to as an indicator. Third, present pathology has developed into various subdivisions and many pathologists have not always specialized in detecting malignant lymphoma disease.

On the absence of a reliable immunohistochemical marker of clonality of T-lymphocytes, genetic study is recommended as the most useful method to detect the presence of a dominant T-cell clone in a lymphocytic infiltrate $[16,17]$. After the 1990s, developments of molecular diagnosis, primary T-cell lymphomas of the thyroid gland were detected accurately, and slightly more cases were reported than before the 1980s. In the present case, PCR could not detect the monoclonality of the TCR; however, monoclonality of the proliferated lymphoid cells was seen on Southern blot analysis.

T-cell lymphomas are generally considered to have worse prognoses than B-cell lymphomas. However, with the exception of three, all reported patients with T-cell lymphomas did not die from the disease.

Treatment of thyroid T-cell lymphoma has focused on a combination of chemoradiotherapy and surgery, but no consensus has been reached. In the present case, only surgical resection was performed without chemotherapy or irradiation. This was because histology of the tumor showed that it was a low-grade lymphoma without extra-capsule spread. In addition, pathologically we found lymph node metastasis. Furthermore, the patient was a little old for chemotherapy and $\mathrm{T}$ cell lymphoma is generally resistant to chemotherapy or irradiation. Based on the literature available, we considered that adjuvant chemoradiotherapy could not contribute to a better prognosis than surgery alone (Table 1).

However, further investigations are needed to clarify this matter.

\section{Conclusions}

Here we emphasized that a very rare case of peripheral T-cell lymphoma of thyroid gland with Hashimoto's thyroiditis was effectively diagnosed by the gene rearrangement procedure. Particularly, patients with rapid thyroid enlargement accompanied with Hashimoto's thyroiditis should also be examined by the gene rearrangement procedure.

\section{Consent}

Written informed consent was obtained from the patient for publication of this case report and accompanying images. A copy of the written consent is available for review by the Editor-in-Chief of this journal.

\section{Abbreviations}

CT: Computed tomography; FDG-PET: 18 F-Fluorodeoxy glucose-Positron Emission Tomography; TCR: T-cell receptor; PCR: Polymerase chain reactions; IgH: Immunoglobulin heavy chain.

\section{Competing interests}

The authors declare that they have no competing interests.

\section{Acknowledgments}

This study was supported in part by Grants-in Aid for Scientific Research from the Ministry of Education, Culture, Sports, and Technology (22591920) of Japan.

\section{Author details}

${ }^{1}$ Department of Otolaryngology, Head and Neck Surgery, Juntendo University School of Medicine, Tokyo, Japan. '2Department of Hematology, Juntendo University School of Medicine, Tokyo, Japan. ${ }^{3}$ Department of Otolaryngology, Kyushu Rosai Hospital, Kitakyushu, Japan.

\section{Authors' contributions}

$J Y$ and SI prepared and edited this manuscript. SO, ES, NK and MF contributed to the collection of data. $\mathrm{MH}$ performed the statistical analysis. $J Y$ and $\mathrm{KI}$ gave final approval for this version of the manuscript. All authors read and approved the final manuscript.

\section{Received: 7 November 2011 Accepted: 19 April 2012}

Published: 19 April 2012

\section{References}

1. Jaffe E, Harris NL, Stein H, Vardiman L (Eds): World Health Organization Classification of Tumours. Pathology and Genetics of Tumours of Haematopoietic and Lymphoid Tissues. Lyon, France: IARC Press; 2001.

2. Diss TC, Watts M, Pan LX, Burke M, Linch D, Isaacson PG: The polymerase chain reaction in the demonstration of monoclonality in $T$ cell lymphomas. J Clin Pathol 1995, 48:1045-1050.

3. Dunbar JA, Lyall MH, MacGillivray JB, Potts RC: T-cell lymphoma of the thyroid. BMJ 1977, 2:679.

4. Mizukami Y, Michigishi T, Nonomura A, Nakamura S, Hashimoto T, Katsuda S, Otake S, Matsubara F: Primary lymphoma of the thyroid: a clinical, histological and immunohistochemical study of 20 cases. Histopathology 1990, 17:201-209.

5. Abdul-Rahman ZH, Gogas HJ, Tooze JA, Anderson B, Mansi J, Sacks NP, Finlayson CJ: T-cell lymphoma in Hashimoto's thyroiditis. Histopathology 1996, 29:455-459.

6. Yamaguchi M, Ohno T, Kita K: (gamma)/(delta) T-cell lymphoma of the thyroid gland. N Engl J Med 1997, 336:1391-1392.

7. Coltrera MD: Primary T-cell lymphoma of the thyroid. Head Neck 1999, 21:160-163.

8. Forconi F, Bocchia M, Marconcini S, Bigazzi C, Milani M, Fraternali-Orcioni G, Lauria F: CD30 positive (nonanaplastic) peripheral T-cell lymphoma of the thyroid gland. Haematologica 1999, 84:946-948.

9. Haciyanli M, Erkan N, Yorukoglu K, Sagol O, Harmancioglu O: Primary non-Hodgkin's T-cell lymphoma of the thyroid gland complicating Hashimoto's thyroiditis: case report. Thyroid 2000, 10:717-720.

10. Raftopoulos I, Vanuno D, Kouraklis G: Two unusual sites of colon cancer metastases and a rare thyroid lymphoma. Case 3 Primary T-cell lymphoma of the thyroid arising in a background of Hashimoto's thyroiditis. J Clin Oncol 2001, 19:3576-3580.

11. Motoi N, Ozawa Y: Malignant T-cell lymphoma of the thyroid gland associated with Hashimoto's thyroiditis. Pathol Int 2005, 55:425-430.

12. Okamoto A, Namura K, Uchiyama H, Kajita Y, Inaba T, Nakamura $S$, Shimazake C: Cytotoxic T-cell non-Hodgkin's lymphoma of the thyroid gland. Am J Hematol 2005, 80:77-78. 
13. Colović M, Matić S, Kryeziu E, Tomin D, Colović N, Atkinson HD: Outcomes of primary thyroid non-Hodgkin's Lymphoma: a series of nine consecutive cases. Med Oncol 2007, 24:203-208.

14. Koida S, Tsukasaki K, Tsuchiya T, Harasawa H, Fukushima T, Yamada Y, Ohshima K, Kamihira S, Kikuchi M, Tomonaga M: Primary T-cell lymphoma of the thyroid gland with chemokine receptors of Th1 phenotype complicating autoimmune thyroiditis. Haematologica 2007, 92:37-40.

15. Yang $\mathrm{H}$, Li J, Shen T: Primary T-cell lymphoma of the thyroid: case report and review of the literature. Med Oncol 2008, 25:462-466.

16. Singer JA: Primary lymphoma of the thyroid. Am Surg 1998, 64:334-337.

17. Fodinger M, Buchmayer H, Schwarzinger I, Simonitsch I, Winkler K, Jager U, Knobler R, Mannhalter C: Multiplex PCR for rapid detection of T-cell receptor-gamma chain gene rearrangements in patients with lymphoproliferative diseases. Br J Haematol 1996, 94:136-139.

doi:10.1186/1477-7819-10-58

Cite this article as: Yokoyama et al.: Problems of primary T-cell

lymphoma of the thyroid gland -A case report. World Journal of Surgical Oncology 2012 10:58.

\section{Submit your next manuscript to BioMed Central and take full advantage of:}

- Convenient online submission

- Thorough peer review

- No space constraints or color figure charges

- Immediate publication on acceptance

- Inclusion in PubMed, CAS, Scopus and Google Scholar

- Research which is freely available for redistribution 